\title{
Forest thinning may increase water yield from the Sierra Nevada
}

About 60\% of California's developed water supply originates in the Sierra Nevada.
$\mathrm{D}$ iscussions of California's limited water
supplies often leave out the biggest water users of all — forests.

But an average of roughly $50 \%$ of the precipitation that falls in the Sierra Nevada never makes it to the state's rivers, groundwater basins, reservoirs and aqueducts. Instead, it sustains trees and other vegetation, or evaporates.

A team of UC researchers is investigating how thinning forests could increase the water yield of the Sierra Nevada, which supplies about $60 \%$ of the surface water used by California's cities and farms.

The Sierra Nevada Watershed Ecosystem Enhancement Project (SWEEP) builds on prior research that indicates that forest thinning - removing a fraction of trees and other vegetation - can improve the health of remaining trees and reduce the risk of severe wildfire (Bales et al. 2011; Collins et al. 2014).

The research team aims to quantify how investments in forest management translate to increases in the amount of runoff from a given watershed. While research from a variety of sites around the world shows that thinning can increase water yield, the magnitude of that effect varies widely depending on climate, elevation and other variables, and it isn't well studied in the Sierra Nevada.

Better data on the benefits of vegetation management - for water availability as well as forest health, fire vulnerability, wildlife habitat and other ecosystem services - could form the basis for deals creating new sources of funding for forest management. Owners of hydroelectric dams, for instance, might chip in for watershed management if it was clearly established that a healthier forest would mean more water flowing through turbines downstream. But such transactions would need to be based on solid research.

"You need good data if you're going to ask people to pay for it," said Roger Bales, a hydrologist and professor of engineering at UC Merced and a lead SWEEP researcher.

Marketing the ecosystem benefits of forest thinning could help address a key problem in forest management: While there is wide agreement that tree density is higher than desirable on much California forestland, funding is scarce for thinning, which typically costs $\$ 300$ to $\$ 500$ per acre. Preliminary estimates suggest that reducing forest cover by $40 \%$ could be expected to increase water yield about $9 \%$.

Bill Stewart, a UC Cooperative Extension specialist who is studying the economic aspects of SWEEP, 


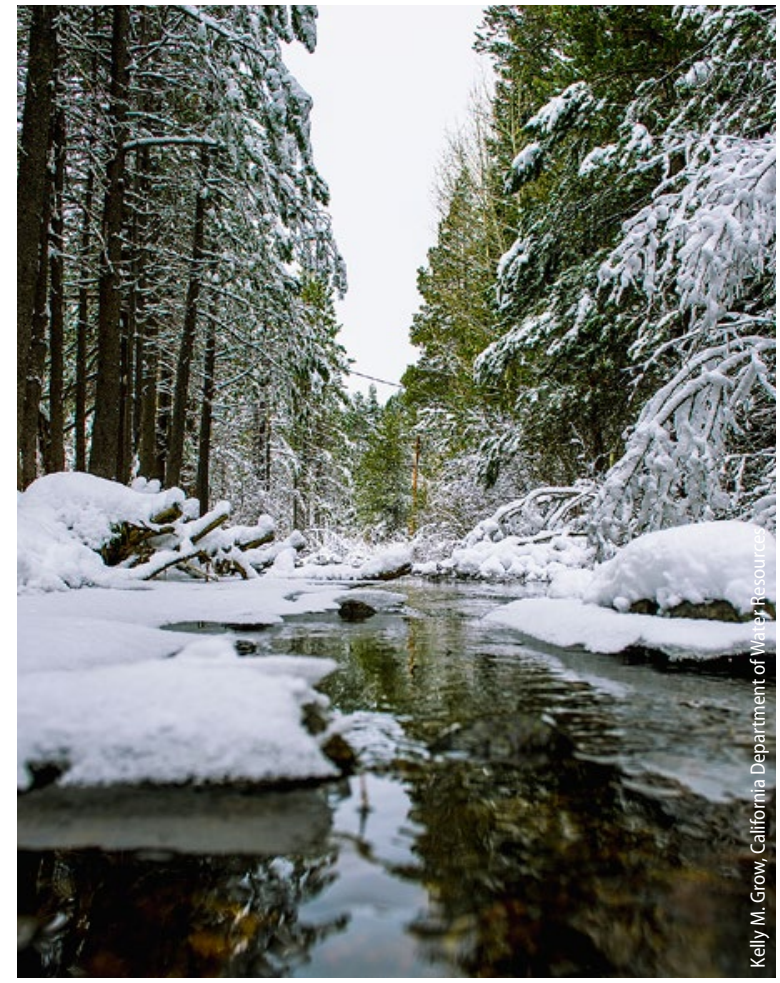

said that the additional water generated by a thinning project is, on its own, not likely to be worth enough to cover costs. In addition, such water benefits likely would be tough to monetize and sell, because they would fluctuate a great deal from year to year. In very dry years, for instance, a thinned forest generally won't yield appreciably more water than a dense one.

But, Stewart said, it does appear that combining revenue from multiple sources - money from sawlogs (harvested trees that can be milled into lumber), biomass power generation, contributions from groups with a stake in fire risk reduction, payments from hydroelectric generators and so on - could cover the cost of thinning, even without taking into account possible payments from downstream water users.

"The water is the icing on the cake," he said.

Restoring vegetation densities to pre-fire-suppression levels through thinning could increase California's usable water supply meaningfully, according to calculations by Bales. He estimates that

\footnotetext{
Further reading:

Bales RC, Battles JJ, Chen Y, et al. 2011. Forests and Water in the Sierra Nevada: Sierra Nevada Watershed Ecosystem Enhancement Project. Sierra Nevada Research Institute report number 11.1. http://ucanr. edu/sites/cff/files/146199.pdf.

Collins BM, Das AJ, Battles JJ, et al. 2014. Beyond reducing fire hazard: fuel treatment impacts on overstory tree survival. Ecol Appl 24:1879-86.

Goulden ML, Bales RC. 2014. Mountain runoff vulnerability to increased evapotranspiration with vegetation expansion. P Natl Acad Sci USA 111:14071-5.
}

Recent snowfall near the headwaters of the South Fork of the American River in the Eldorado National Forest. Climate change is expected to decrease average winter snowpack in the Sierra Nevada $25 \%$ by 2050 .

thinning 500,000 to 600,000 acres of forest would increase average water yield by 100,000 acre-feet.

However, Bales notes, recent research indicates that some of this potential water gain from thinning would be lost to higher rates of evapotranspiration as the climate warms. A 2014 study co-authored by Bales shows how a warming climate will drive increased vegetation and water consumption at high elevations as plant communities expand

\section{Thinning 500,000 to 600,000 acres of forest could increase average water} yield by 100,000 acre-feet.

uphill and warmer tem-

peratures extend the growing season (Goulden and Bales 2014).

The changing climate also is expected to decrease average winter snowpack $25 \%$ by 2050 , a major reduction to a natural storage system that has historically held an average of 15 million acre-feet of water that is gradually released during spring, summer and fall.

These worrisome trends are driving increased concern about water yield from the Sierra Nevada. The scope of thinning contemplated by land managers and the SWEEP researchers could ameliorate these climate-driven reductions to some degree.

SWEEP, which launched in 2011, is still in its early stages. Supported by a UC Agriculture and Natural Resources grant, the team is currently working on detailed planning and funding for what is expected to be a decade-long field research effort. CA - Jim Downing

Ponderosa pine stand near Blodgett Forest Research Station in El Dorado County. Lessdense forests tend to yield more water.

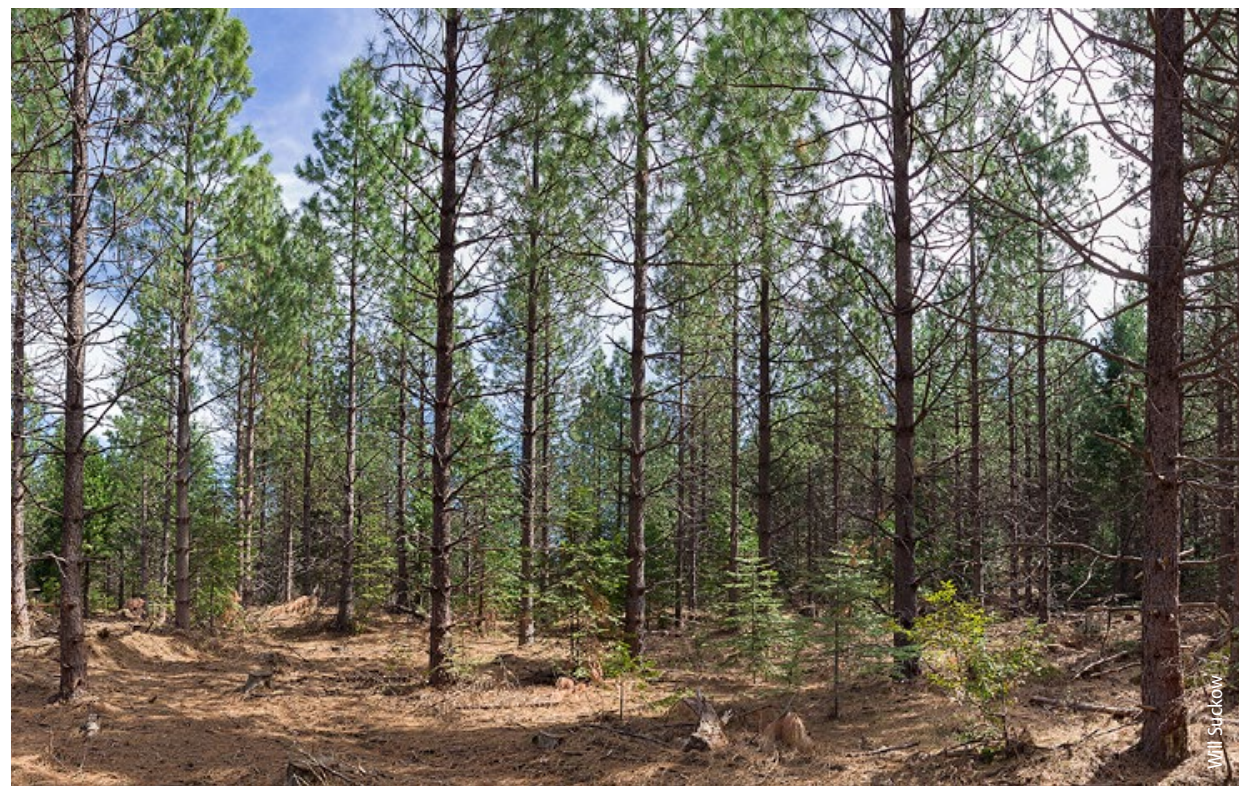

